\title{
PENGUATAN PENDIDIKAN KARAKTER BERBASIS PANCASILA PADA SISWA DI ERA REVOLUSI INDUSTRI 4.0
}

\author{
OLEH: \\ WINNING AMINTAS KARTIKA WARUWU ${ }^{1}$,SITI MAYANG SARI ${ }^{2}$, JALALUDDIN $^{3}$ \\ (AKPER KESDAM I/BB MEDAN ${ }^{1}$, STKIP BINA BANGSA MEULABOH ACEH²,UNIVERSITAS SERAMBI MEKKAH ${ }^{3}$ )
}

\begin{abstract}
ABSTRACKT
Character is an application of the value of goodness in which there is character, mental and moral qualities that must be applied and instilled in students so that they become beings who have good character and dignified personality. Therefore, character education is an important part in building a student's identity. Character development must be based on Pancasila values. Building the next generation of a nation with good character is the responsibility of all walks of life, because our true responsibility for education together, of course this is not an easy matter, therefore it requires awareness from all parties that character education is very important to be implemented. Seeing the phenomenon of the industrial era 4.0 is a challenge to pay attention to the character of students.

The planting of nationalism based on Pancasila as the state ideology needs to be done to deal with potential threats in the future. The industrial revolution 4.0 was an era in which massive changes occurred in various fields and had a profound impact that could not be separated also in terms of the character development of elementary students. These characters which will become the basic capital of students can compete in the international and national world later. Especially in the face of the industrial revolution 4.0. Strong character also forms a formidable personality of students so that they are not easily influenced by negative things as the industrial revolution 4.0 goes on. Therefore, Pancasila must be implemented as early as possible in learning to make the character of elementary school students in the era of the industrial revolution 4.0 much better.
\end{abstract}

\section{Keywords: Character of Elementary School Students, Pancasila, Industrial Revolution 4.0.}

\section{PENDAHULUAN}

\section{Latarbelakang}

Seiring perkembangan zaman, dan pengaruh globalisasi yang terusmenerus terjadi di Indonesia, menuntut pendidik untuk menguasai ilmu pengetahuan dan teknologi, dan memiliki keterampilan yang membuatnya ikut berkembang dan tidak tertinggal oleh perkembangan zaman. Pendidikan karakter menjadi hal yang penting untuk menghadapi tantangan lokal, nasional, dan global. Tanpa adanya pendidikan karakter yang bermutu, ilmu pengetahuan dan teknologi, dan keterampilan maka siswa tidak akan memiliki kepribadian yang baik. 
Seiring berjalannya waktu dan jaman semakin berkembang dimana sering kita sebut sebagai revolusi industry 4.0, maka kita sebagai pendidik harus dapat menyikapi perubahan tersebut. Era revolusi industri 4.0 merupakan tantangan berat bagi guru Indonesia. Pendidikan dan pembelajaran yang syarat dengan muatan pengetahuan mengesampingkan muatan sikap dan keterampilan sebagaimana saat ini terimplementasi, akan menghasilkan peserta didik yang tidak mampu berkompetisi dengan mesin. Pada abad 21 ini, pendidik dituntut untuk memiliki semangat belajar yang tinggi dan kemampuan mengajar yang mumpuni. Itu artinya, pendidik merupakan pilar pendidikan yang sangat vital perannya. Keberhasilan pendidikan sangat tergantung pada peran strategis guru.

Pendidik dituntut untuk melahirkan generasi muda yang mampu menghadapi era revolusi industri 4.0, dimana peran manusia mengalami disrupsi dengan banyaknya peran manusia tergantikan dengan mesin-mesin dan kecerdasan buatan. Sistem pendidikan membutuhkan gerakan kebaruan untuk merespon era industri 4.0. Salah satu gerakan yang dicanangkan oleh pemerintah adalah gerakan literasi baru sebagai penguat bahkan menggeser gerakan literasi lama. Gerakan literasi baru yang dimaksudkan terfokus pada tiga literasi utama yaitu 1) literasi digital, 2) literasi teknologi, dan 3) literasi manusia (Aoun, 2018). Tiga keterampilan ini diprediksi menjadi keterampilan yang sangat dibutuhkan di masa depan atau di era industri 4.0. Literasi digital diarahkan pada tujuan peningkatan kemampuan membaca, menganalisis, dan menggunakan informasi di dunia digital (Big Data), literasi teknologi bertujuan untuk memberikan pemahaman pada cara kerja mesin dan aplikasi teknologi, dan literasi manusia diarahkan pada peningkatan kemampuan berkomunikasi dan penguasaan ilmu desain (Aoun, 2017).

Berbicara perihal karakter siswa sekarang bisa dikatakan mulai rapuh. Ad banyak dampak negative misalnya siswa menjadi malas belajar, karena tersedianya peralatan yang seharusnya dapat memudahkan siswa dalam belajar, seperti Laptop dengan jaringan internet, ini malah sering membuat siswa menjadi malas belajar, terkadang banyak diantara mereka yang menghabiskan waktunya untuk internetan yang hanya mendatangkan kesenangan semata, contohnya 
bermain game dan bermain media social, selain itu terjadinya pelanggaran asusila, dan berbagai tindakan penyalahgunaan teknologi. Perkembangan teknologi membawa dampak besar bagi siswa dimana mengakibatkan kurangnya sosialisasi antar teman, antar guru. Karena masing-masing siswa sudah banyak yang memiliki teknologi sendiri sehingga tidak ada terjalin komunikasi. Tidak hanya itu, revolusi industri 4.0 dapat membuat peserta didik melupakan nilai-nilai yang terkandung dalam Pancasila. Pancasila merupakan sebuah nilai yang seharusnya diaplikasikan ke dalam kehidupan nyata. Untuk itu pendidikan karakter merupakan salah satu upaya untuk merubah karakter siswa sekolah dasar berbasis Pancasila di era revolusi industri 4.0.

Nilai - Nilai yang terdapat pada Pancasila mengandung moral, nilai-nilai yang luhur serta budaya Bangsa Indonesia yang berharga, baik, berguna, sarat dengan makna, isi, pesan, semangat, serta jiwa yang tersurat serta tersirat dalam fakta, konsep, dan teori dengan makna secara fungsional yang diamalkan dalam kehidupan sehari-hari maka dapat memberi manfaat bagi seluruh warga Indonesia untuk mengarahkan, menentukan, dan mengendalikan kelakuan seseorang ( Winarno, 2007). Selain itu, dengan adanya pengamalan nilai-nilai pancasila pada kehidupan sehari-hari, maka kita selaku Warga Negara Indonesia akan terbentuk sebagai warga Negara yang mampu memahami dan melaksanakan hak-hak dan kewajibannya untuk tampil lebih baik, cerdas, terampil, serta berkarakter sejalan dengan amanat Pancasila serta UUD 1945 yang dapat mempertahankan tegaknya Negara Kesatuan Republik Indonesia (Rahmawati, et al., 2007).

Berdasarkan tututan dari generasi ke tiap tahap generasi perlu bimbingan yang ter arah tepatnya pada sisi sikap dan karakter agar menjadi warga negara yang baik dan cerdas adalah karakter yang sesuai dan ditunjukkan sikap yang berkaitan dengan nilai-nilai yang terkandung dalam Pancasila.Nilai karakter yang terkadung dalam tiap sila Pancasila yaitu nilai karakter yang religius, peduli sosial, kemandirian, patriotisme, kebersamaan, demokratis, dan adil.

Pendidikan karakter berbasis Pancasila harus ditanamkan sejak peserta didik duduk dibangku sekolah dasar. Karena pada tahap awal ini peserta didik sangat mudah menerima dan mencontoh apa yang mereka lihat dengan nyata. Untuk itu 
penanaman nilai-nilai Pancasila harus diintegrasikan dalam proses pembelajaran sehingga nantinya dapat di aplikasikan oleh peserta didik dalam kehidupan nyata.

\section{Karakter Siswa Sekolah Dasar}

Menurut Kamisa,pengertian karakter merupakan sifat kejiwaan, akhlak serta budi pekerti yang dimiliki seseorang yang membuatnya berbeda dibandingkan dengan orang lainnya. Berkarakater juga dapat diartikan sebagai memiliki sebuah watak serta kepribadian. Menurut H.Soemarno dalam Merli (2011:25) Karakter merupakan nilai-nilai yang terpatri dalam diri kita melalui pendidikan, pengalaman, percobaan, pengorbanan, dan pengaruh lingkungan, dipadukan dengan nilai nilai dari dalam diri manusia menjadi semacam nilai intrinsik yang mewujud dalam system daya juang melandasi pemikiran, sikap dan perilaku kita. Menurut T. Ramli, pengertian pendidikan karakter adalah pendidikan yang mengedepankan esensi dan makna terhadap moral dan akhlak sehingga hal tersebut akan mampu membentuk pribadi peserta didik yang baik.

Menurut John W. Santrock, character education adalah pendidikan yang dilakukan dengan pendekatan langsung kepada peserta didik untuk menanamkan nilai moral dan memberi kan pelajaran kepada murid mengenai pengetahuan moral dalam upaya mencegah perilaku yang yang dilarang.

Secara umum fungsi pendidikan ini adalah untuk membentuk karakter seorang peserta didik sehingga menjadi pribadi yang bermoral, berakhlak mulia, bertoleran, tangguh, dan berperilaku baik.

Adapun beberapa fungsi pendidikan karakter adalah sebagai berikut;

1. Untuk mengembangkan potensi dasar dalam diri manusia sehingga menjadi individu yang berpikiran baik, berhati baik, dan berperilaku baik.

2. Untuk membangun dan memperkuat perilaku masyarakat yang multikultur.

3. Untuk membangun dan meningkatkan peradaban bangsa yang kompetitif dalam hubungan internasional.

Menyikapi tujuan pendidikan budaya dan karakter yang dikemukakan oleh puskur, tentunya hal ini menjadi perhatian bagi para guru untuk membentuk karakter peserta didik sejak duduk dibangku sekolah dasar. Karakter harus ditanamkan sejak dini, karena masa-masa ini akan lebih mudah diterapkan pada 
anak. Apalagi untuk anak-anak yang duduk dibangku sekolah dasar, mereka belum terkontaminasi dengan pengaruh globalisasi disamping peran guru, orangtua dan masyarakat yang selalu gigih dalam membimbing dan mendidik mereka.

Character education seharusnya dilakukan sejak dini, yaitu sejak masa kanak-kanak. Pendidikan ini bisa dilakukan di lingkungan keluarga, sekolah, dan lingkungan, serta memanfaatkan berbagai media belajar. Menurut kamus bahasa Indonesia (2003) kata "inovasi” mengangdung arti pengenalan hal-hal yang baru atau pembaharuan". Inovasi juga berarti penemuan baru yang berbeda dari yang sudah ada atau yang sudah dikenal sebelumnya (gagasan, metode, atau alat). Jadi pembelajaran inovatif dapat diartikan sebuah pembelajaran yang menggunakan strategi/metode baru yang dihasilkan dari penemuannya sendiri atau menerapkan metode baru yang ditemukan oleh para pakar dan didesain sedemikian rupa sehingga dapat menciptakan pembelajaran yang kondusif.

Pembelajaran inovatif juga mengandung arti pembelajaran yang dikemas oleh guru atau instruktur lainnya yang merupakan wujud gagasan atau teknik yang dipandang baru agar mampu menfasilitasi siswa untuk memperoleh kemajuan dalam proses dan hasil belajar. Pembelajaran inovatif bisa mengadaptasi dari model pembelajaran yang menyenangkan. "Learning is fun" merupakan kunci yang diterapkan dalam pembelajaran inovatif. Jika siswa sudah menanamkan hal ini di pikirannya tidak akan ada lagi siswa yang pasif di kelas, perasaan tertekan, kemungkinan kegagalan, keterbatasan pilihan, dan tentu saja rasa bosan. Membangun metode pembelajaran inovatif sendiri bisa dilakukan dengan cara diantaranya mengakomodir setiap karakteristik diri. Artinya mengukur daya kemampuan serap ilmu masing-masing orang.

Syah dan Kariadinata (2009: 16) Pembelajaran inovatif dapat menyeimbangkan fungsi otak kiri dan kanan apabila dilakukan dengan cara mengintegrasikan media/alat bantu terutama yang berbasis teknologi baru/maju ke dalam proses pembelajaran tersebut. Pembelajaran yang inovatif juga tercermin dari hasil yang diperlihatkan siswa yang komunikatif dan kolaboratif dalam mengartikulasikan pikiran dan gagasan secara jelas dan efektif melalui tuturan 
lisan dan tulisan. Siswa dengan karakteristik semacam ini dapat menunjukkan kemampuan untuk bekerja secara efektif dalam tim yang beraneka, untuk memainkan fleksibilitas dan kemauan berkompromi dalam mencapai tujuan bersama.

Guru harus mampu mengemas proses pembelajaran menjadi inovatif. Menurut setiawan (2012) pembelajaran inovatif terdiri dari, pendekatan student centered, multi model dan metode, multimedia, multi sumber belajar, pembelajaran konstekstual, evaluasi yang berbasis kognitif, afektif dan psikomotorik, posisi guru sebagai director of learning. Pembelajaran inovatif dilakukan unuk meningkatkan karakter dan membuat pembelajaran menjadi lebih bermakna.

\section{Nilai-nilai Pancasila}

Pancasila adalah ideologi dasar dalam kehidupan bagi negara Indonesia. Nama ini terdiri dari dua kata dari Sanskerta: pañca berarti lima dan śīla berarti prinsip atau asas. Pancasila merupakan rumusan dan pedoman kehidupan berbangsa dan bernegara bagi seluruh rakyat Indonesia. Hariyono (2014) mengatakan bahwa kepentingan bangsa dan Negara selalu menempati posisi yang dominan dalam perumusan Pancasila sebagai dasar Negara maupun sebagai pandangan hidup bangsa. Untuk itu, Pancasila adalah suatu hal yang tidak dapat dipisahkan dalam kehidupan.

Moerdiono dalam Setiawan (2014:130) menunjukkan adanya 3 tataran nilai dalam ideologi Pancasila, yaitu : 1. Nilai dasar, yaitu suatu nilai yang bersifat amat abstrak dan tetap, yang terlepas dari pengaruh perubahan waktu. Nilai dasar Pancasila ditetapkan oleh para pendiri negara. Nilai dasar Pancasila tumbuh baik dari sejarah perjuangan bangsa Indonesia melawan penjajahan yang telah menyengsarakan rakyat, maupun dari cita-cita yang ditanamkan dalam agama dan tradisi tentang suatu masyarakat yang adil dan makmur berdasarkan kebersamaan, pesatuan dan kesatuan seluruh warga masyarakat. 2. Nilai instrumental, yaitu suatu nilai yang bersifat konstektual. Nilai instrumental merupakan penjabaran dari nilai dasar, yang merupakan arahan kinerjanya untuk kurun waktu tertentu dan kondisi tertentu. 3. Nilai praksis, yaitu nilai yang terkandung dalam 
kenyataan sehari-hari, berupa cara bagaimana rakyat melaksanakan (mengaktualisasikan) nilai Pancasila.

Dimensi peran guru sebagai pelestari Pancasila antara lain; Sila pertama, Ketuhanan Yang Maha Esa. Seorang guru menampilkan dirinya sebagai sosok yang religius, rajin beribadah, dan menjadi pelopor mengajak peserta didik warga sekitar untuk meningkatkan keimanan dan ketakwaan terhadap Tuhan YME. Ketika mengajar di dalam kelas, guru dapat mengimplementasikan nilai-nilai ketuhanan dalam bentuk mengajar peserta didik berdo'a pada saat memulai dan mengakhiri pelajaran, mengaitkan materi pelajarannya yang diajarkannya dengan nilai-nilai ketuhanan untuk meningkatkan keimanan dan ketakwaan peserta didik, melaksanakan kegiatan-kegiatan keagamaan, dan sebagainya

Sila kedua, kemanusiaan yang adil dan beradab. Seorang guru harus memiliki dan mengamalkan nilai-nilai kemanusiaan. Hakikat dari pendidikan adalah untuk memanusiakan manusia. Oleh karena itu, guru harus memperlakukan setiap peserta didiknya secara manusiawi, dan menginternalisasikan nilai-nilai kemanusiaan kepada mereka agar menjadi manusia-manusia yang menjunjung tinggi nilai-nilai kemanusiaan. Guru mengajarkan peserta didik budaya saling memaafkan, budaya saling membantu, budaya peduli terhadap kesulitan orang lain.

Sila ketiga, persatuan Indonesia. Guru harus menjadi sosok pemersatu bangsa. Guru dapat menjadi figur yang mampu meredam konflik-konflik di lingkungan peserta didik. Sila keempat, kerakyatan yang dipimpin oleh hikmat kebijaksanaan dalam permusyawaratan/perwakilan. Seorang guru perlu mengedepankan musyawarah mufakat dalam mengambil keputusan, jangan selalu mengedepankan pemilihan melalui suara terbanyak (voting). Di kelas, guru membiasakan peserta didik untuk mengambil keputusan melalui musyawarah mufakat agar mereka ketika mereka terjun di masyarakat juga melakukan hal yang sama. Keputusan yang diambil secara musyawarah mufakat akan menimbulkan rasa memiliki, rasa menghormati, dan rasa tanggung jawab terhadap keputusan yang telah disepakati bersama. 
Sila kelima, keadilan sosial bagi seluruh rakyat Indonesia. Guru dapat mempelopori terwujudnya keadilan bagi setiap manusia yang implementasinya dimulai dari lingkungan yang paling kecil seperti bertindak adil kepada diri sendiri, anggota keluarga, peserta didik, dan masyarakat. Di kelas tidak diskriminatif, memperlakukan setiap peserta didik sesuai tingkat perkembangan berpikirnya, menghargai pendapat dan hasil karya peserta didik, melakukan penilaian otentik, dan memberikan remedial bagi peserta didik yang belum mencapai Kriteria Ketuntasan Minimal (KKM).

\section{HASIL PENELITIAN}

\section{Revolusi Industri 4.0 Sejarah revolusi industri dimulai dari industri 1.0, 2.0,}

\section{0, sampai industri 4.0.}

Revolusi industri 4.0 merupakan perubahan fundamental di bidang industri yang telah memasuki era baru. Gelombang keempat dari perjalanan dan perkembangan revolusi industri. Sebab itulah disebut dengan revolusi industri 4.0 Secara sederhana, revolusi industri 4.0 dapat dipahami sebagai perkembangan teknologi pabrik yang mengarah pada otomasi dan pertukaran data terkini secara mudah dan cepat yang mencakup sistem siber-fisik, internet untuk segala (internet of things), komputasi awan (cloud computing), dan komputasi kognitif. Otomasi sendiri merupakan sebuah teknik penggunaan mesin yang disertai dengan teknologi dan sistem kontrol guna mengoptimalkan produksi dan pengiriman barang serta jasa. Dalam teknik ini, peran tenaga kerja manusia tak lagi mendominasi, karena kerja mesin-mesin robotik mampu bekerja lebih cepat dengan hasil yang lebih baik dalam kuantitas maupun kualitas.

Secara historis, revolusi industri gelombang pertama terjadi sejak abad ke17 dan berkembang hingga memasuki gelombang keempat pada abad ini.

1. Revolusi industri pertama,Berdasarkan catatan sejarah yang ada, revolusi industri pertama terjadi pada kisaran tahun 1750-1830. Pada gelombang pertama ini, revolusi industri ditandai dengan adanya penemuan mesin uap dan kereta api. Mesin uap digunakan untuk menggantikan tenaga manusia dan hewan dalam proses produksi. 
2. Revolusi industri kedua,Revolusi industri kedua terjadi pada rentang tahun 1870-1900 yang ditandai dengan adanya penemuan listrik, alat komunikasi, minyak, dan bahan-bahan kimia. Berbagai penemuan tersebut mendukung pelaksanaan konsep produksi massal.

3. Revolusi industri ketiga,Revolusi industri gelombang ketiga terjadi mulai tahun 1960 hingga saat ini yang ditandai dengan adanya penemuan komputer, telepon genggam atau ponsel, dan internet. Penemuan-penemuan tersebut tentu saja bermanfaat untuk melakukan otomasi proses produksi dalam kegiatan produksi.

4. Revolusi industri keempat, Dikenal dengan istilah revolusi industri 4.0, di mana era baru ini ditandai dengan berintegrasinya beberapa teknologi sekaligus yaitu biologi, fisika, dan digital. Perpaduan teknologi ini memungkinkan pelaksanaan proses produksi menjadi lebih mudah dan cepat serta produktif.

Revolusi industri 4.0 dikatakan sebagai tantangan jika penggunaan teknologi disalah gunakan oleh siswa sekolah dasar apabila media sosial seperti Facebook, Whatsapp, youtube, Instagram, dan lainnya. Kenyataannya siswa banyak yang kecanduan bermain komputer ditengarai memicu anak menjadi malas menulis, menggambar atau pun melakukan aktivitas social,selain itu para siswa kecanduan game Game digital ini akan menyebabkan kecanduan bagi pengguananya apabila pengguna itu tidak dapat mengendalikan dirinya, sehingga sehari tanpa bermain game itu terasa sangat membosankan. Kecanduan bermain game memang saat ini sudah menjadi trend di kalangan remaja terutama para pelajar, baik game computer maupun laptop game digital ini menyebabkan pelajar menjadi malas untuk belajar, menjadi malas untuk melakukan segala jenis kegiatan seperti membantu orang tua, mengerjakan tugas, hingga malas untuk mandi.

Beda halnya ketika pemanfaatan teknologi di era industri 4.0 jika dijadikan sebagai alat bantu dalam proses pembelajaran. Misalnya menjadi media mendapatinformasi yang dibutuhkan untuk menjadi lebih cepat dan lebih mudah 
dalam mengakses tujuan pendidikan dan bisa menjadi Inovasi dalam pembelajaran tumbuh di hadapan e-learning inovasi yang lebih memudahkan proses pendidikan Simpulannya ialah zaman boleh berkembang, sebaik apapun perkembangan zaman tetap jagalah ketegakan nilai-nilai Pancasila dan tanamkan kepada siswa agar mereka dapat mengamalkannya dalam kehidupan sehari-hari. Jika satu saja nilai Pancasila tidak dilaksanakan maka karakter siswa akan anjlok bahkan tidak lagi memiliki moral.

\section{PENUTUP}

Kesimpulan Revolusi Industri 4.0 harus dijadikan sebagai peluang bagi para pendidik khususnya guru dalam meningkatkan kemajuan pendidikan.

Peran guru profesional dalam pembelajaran sangat penting sebagai kunci keberhasilan belajar peserta didik dan mengahasilkan lulusan yang berkualitas. Guru profesional adalah guru yang kompeten dalam membangun dan mengembangkan proses pembelajaran yang baik dan efektif sehingga dapat menghasilkan siswa berkarakter dan memiliki pendidikan yang berkualitas. Setiap manusia harus dapat menjaga dan merawat memberdayakan sarana teknologi informasi, serta dapat memanfaatkannya dengan sebaik baiknya agar bermanfaat untuk setiap orang. Tidak untuk perbuatan yang menyimpang dan menjadikan perkembangan teknologi informasi sebagai titik balik untuk memajukan pendidikan bangsa yang sudah tertinggal jauh dari negara-negara maju. Karena sesuatu apapun yang kita lakukan sekarang pasti akan berdampak pada masa yang akan datang, begitu juga sarana teknologi informasi dan globalisasi ini. Remaja bentengilah diri anda dengan sekuat mungkin karena kedepan andalah para pemuda bangsa ini

Pendidikan berbasis digital jangan dijadikan sebagai bencana, melainkan tantangan yang harus dipecahkan dan berusaha untuk menjadikan tantangan ini sebagai peluang dalam pendidikan yang lebih berkompeten terutama dalam meningkatkan karakter siswa sekolah dasar yang berbasis nilai-nilai Pancasila. Kemajuan teknologi harus dimanfaatkan dengan sangat baik dan tetap memperhatikan nilai-nilai Pancasila agar nantinya peserta didik dapat menjadi generasi penerus bangsa yang cerdas, terampil dan berkarakter. 
Sebagai bangsa yang mempunyai ideology yang kuat, yaitu Pancasila. Dalam menanggapi perkembangan Teknologi Informasi harus sesuai dengan ideology yang telah menjadi warisan dari para pendiri negara ini. Hal-hal yang tidak sesuai dengan budaya yang telah ada seharusnya tidak diterima di negara ini. Dengan adanya Pancasila dapat memilah mana yang sesuai dengan budaya yang ada, sehingga tidak melunturkan budaya dan sifat Pancasilais bangsa ini yang disebabkan oleh budaya dan perilaku yang masuk karena perkembangan Teknologi Informasi di era globalisasi saat ini.

\section{DAFTAR PUSTAKA}

Azizan, Nashran. 2017. "Penguatan Nilainilai Pancasila Pada Peserta Didik di Sekolah Dasar". Makalah disampaikan pada Seminar Nasional Tahunan Fakultas Ilmu Sosial dengan tema "Pendidikan Ilmu-ilmu Sosial Berwawasan Kebangsaan. Medan: Hotel Arya Duta Medan 20 Oktober 2017.

Andran, C. (2014). Sistem Pendidikan. Retrieved from https://www.kompasiana.com/andreancan/54f76a90a33311b0368b47ea/sis tempendidikan.

Hariyono. 2014. Ideologi Pancasila Roh Progresif Nasionalisme Indonesia. Malang: Intans Publishing.

Ibda, Hamidulloh. 2018. Penguatan Literasi Baru Pada Guru Madrasah Ibtidaiyah Dalam Menjawab Tantangan Era Revolusi Industri 4.0. Journal Of Research And Thought Of Islamic Education, (Online). Vol.1 No.1 2018.

Andran, C. (2014). Sistem Pendidikan. Retrieved from https://www.kompasiana.com/andreancan/54f76a90a33311b0368b47ea/sis tempendidikan.

Intan, A. (2018). Proses Pembelajaran Digital dalam Era Revolusi Industri 4.0. Retrieved from http://belmawa.ristekdikti.go.id/wpcontent/uploads/2018/08/Panduan-Program- SAPDA-Revolusi-Industri4.0.pdf.

Risdianto, E. (n.d.). ANALISIS PENDIDIKAN INDONESIA DI ERA REVOLUSI INDUSTRI 4.0. Retrieved from http://fkip.ums.ac.id/wpcontent/uploads/sites/43/2018/12/Revolusi-Industri-4.0-dan-Dampaknyaterhadap-Pendidikan-di-Indonesia-Dr.-Sukartono.doc. 
Satya, V. E. (2018). STRATEGI INDONESIA MENGHADAPI INDUSTRI 4.0. Retrieved from https://bikinpabrik.id/wp-content/uploads/2019/01/InfoSingkat-X-9-I- P3DI-Mei-2018-249.pdf.

Shaepudin, B. S. (n.d.). REVOLUSI INDUSTRI 4.0 , APAKAH ITU? DAN PENGARUHNYA TERHADAP DUNIA PENDIDIKAN. Retrieved from http://disdikkbb.org/?news=revolusi-industri-4-0-apakah-itu-danpengaruhnya-terhadap-dunia-pendidikan.

Kaelan dan Achmad Zubaidi. 2007. Pendidikan Kewarganegaraan. Yogyakarta :Paradigma.

Winarno. 2007. Paradigma baru Pendidikan Kewarganegaraan (volume 2). Jakarta: Bumi Aksara. 